\title{
Growth and energy metabolism of Nile tilapia juveniles fed glycerol
}

\author{
Diego Vicente da Costa $^{(1)}$, Renan Rosa Paulino(1), Daniel Okamura( ${ }^{(1)}$, Marinez Moraes de Oliveira ${ }^{(1)}$ \\ and Priscila Vieira e Rosa(1)
}

\begin{abstract}
(1)Universidade Federal de Lavras, Departamento de Zootecnia, Caixa Postal 3037, CEP 37200-000 Lavras, MG, Brazil. E-mail: diego@zootecnista.com.br, renanrpaulino@hotmail.com, danielokamura@hotmail.com, marinez.moraes@ig.com.br, priscila@dzo.ufla.br
\end{abstract}

\begin{abstract}
The objective of this work was to evaluate the effect of inclusion of dietary glycerol in replacement to starch on the growth and energy metabolism of Nile tilapia juveniles. The experiment was carried out in a completely randomized design with four treatments $(0,5,10$, and $15 \%$ purified glycerol) and six replicates. Pelleted, isonitrogenous, and isocaloric diets were provided for 60 days. Growth performance parameters and muscle glucose and protein concentrations were not affected by dietary glycerol levels. The treatment with $15 \%$ glycerol presented higher levels of muscle and liver triglycerides. A quadratic effect of treatments on muscle and liver triglyceride concentrations was observed. The treatment with $0 \%$ glycerol presented higher hepatic glucose levels than the one with $15 \%$. Treatments did not differ for concentrations of liver protein, as well as of plasma glucose, triglycerides, and protein. Treatments with 10 and $15 \%$ glycerol showed higher activity of the glucose-6-phosphate-dehydrogenase enzyme than the treatment with 5\%; however, there were no significant differences in the hepatic activities of the malic and glycerol kinase enzymes. A linear positive effect of treatments was observed on the activity of the glycerol kinase enzyme in liver. Levels of glycerol inclusion above $10 \%$ in the diet of Nile tilapia juveniles characterize it as a lipogenic nutrient.
\end{abstract}

Index terms: Oreochromis niloticus, alternative feed, carbohydrate, nutrition.

\section{Crescimento e metabolismo energético de juvenis de tilápia-do-nilo alimentados com glicerol}

Resumo - O objetivo deste trabalho foi avaliar o efeito da inclusão de glicerol na dieta, em substituição ao amido, sobre o desempenho e o metabolismo energético de juvenis de tilápia-do-nilo. $\mathrm{O}$ experimento foi conduzido em delineamento inteiramente casualizado com quatro tratamentos $(0,5,10$ e $15 \%$ de glicerol purificado) e seis repetições. Dietas peletizadas, isonitrogenadas e isoenergéticas foram fornecidas por 60 dias. Os parâmetros de desempenho produtivo e as concentrações de glicose e proteína muscular não foram afetados pelos níveis de glicerol na dieta. O tratamento com $15 \%$ de glicerol apresentou maiores níveis de triglicerídeos musculares e hepáticos. Observou-se efeito quadrático dos tratamentos nas concentrações de triglicerídeos no músculo e no fígado. O tratamento com $0 \%$ de glicerol apresentou maiores níveis de glicose hepática do que o tratamento com $15 \%$. Os tratamentos não diferiram quanto às concentrações de proteína no fígado, bem como de glicose, triglicerídeos e proteína no plasma. Os tratamentos com 10 e $15 \%$ de glicerol apresentaram maiores atividades da enzima glicose-6-fosfato-desidrogenase do que o tratamento com 5\%; no entanto, não houve diferenças significativas nas atividades hepáticas das enzimas málica e glicerol quinase. Observou-se efeito linear positivo dos tratamentos na atividade da enzima glicerol quinase no fígado. Níveis de inclusão de glicerol acima de $10 \%$ na dieta de juvenis de tilápia-do-nilo o caracterizam como nutriente lipogênico.

Termos para indexação: Oreochromis niloticus, alimentos alternativos, carboidratos, nutrição.

\section{Introduction}

Aquaculture, as opposed to stagnating extractive fish production, has greatly developed worldwide in recent years. World production of food-fish aquaculture expanded at an average annual rate of $6.2 \%$ in the period of 2000-2012, and Brazil has improved its global ranking significantly (Food and Agriculture Organization of the United Nations, 2014). However, intensive fish production still faces some obstacles that hinder its expansion, such as the dependence on finite or scarce feeds, considering that more than 50\% of total production costs are attributed to fish feeding. The limited amount of feeds available has resulted 
in massive research to identify alternative ingredient sources (Olsen \& Hasan, 2012), in order to replace finite or expensive feeds, without affecting fish growth performance and healthiness.

One of the alternative ingredients that may be applied in fish feeding is glycerol, due to its current excess in the market as a result of the recent increase in worldwide biodiesel production. Glycerol is a simple polyol compound with three hydroxyl groups and low molecular weight, which is colorless, odorless, sweet-tasting, and generally recognized as safe for consumption when used in accordance with good manufacturing practices (United States Food and Drug Administration, 2013). The biodiesel production process generates large amounts of crude glycerol or glycerin, which is the main coproduct and represents approximately $10 \%$ of the total production of biodiesel. The percentage of glycerol in glycerin ranges from 65 to $85 \%(\mathrm{w} / \mathrm{w})$, and most of the impurities, such as free fatty acids, esters, salt, and residual alcohol, are formed by the reaction of lipids with alcohol in the presence of a catalyst.

Therefore, aquaculture may benefit from including glycerol as an alternative energy source in fish diet. However, the glycerin found in the market has a nonstandard composition, which requires a purified source of glycerol in order to nullify the effects of glycerin impurities and to understand the effect of its main component on fish growth and energy metabolism.

Glycerol has been studied as a dietary energy source in several nonruminant animal cultures, such as poultry (Lima et al., 2012), swine (Shields et al., 2012), rabbit (Retore et al., 2012), and dogs (Lima et al., 2014). However, little is known about its inclusion in Nile tilapia (Oreochromis niloticus) diet. Neu et al. (2013) demonstrated that diets containing up to $100 \mathrm{~g} \mathrm{~kg}^{-1}$ glycerin did not affect carcass composition and growth performance of Nile tilapia juveniles. Gonçalves et al. (2015) found lower weight gain in Nile tilapia juveniles fed $160 \mathrm{~g} \mathrm{~kg}^{-1}$ glycerin than in those fed 40 and $80 \mathrm{~g} \mathrm{~kg}^{-1}$. However, none of those studies evaluated the influence of a purified source of dietary glycerol on growth performance, tissue metabolites, and enzyme activities of Nile tilapia juveniles.

The objective of this work was to evaluate inclusion levels of dietary glycerol in replacement to starch on the growth and energy metabolism of Nile tilapia juveniles.

\section{Materials and Methods}

The experiment was conducted at the Fisheries Sector of the Department of Animal Science of Universidade Federal de Lavras, in the state of Minas Gerais, Brazil.

Nile tilapia juveniles, with initial weight and length of $37.7 \pm 10.6 \mathrm{~g}$ and $13.02 \pm 1.09 \mathrm{~cm}$ (mean $\pm \mathrm{SD}$ ), respectively, were used. The experimental adaptation period of the animals to laboratory conditions was of 10 days, in which fish were kept at $29 \pm 0.1^{\circ} \mathrm{C}$ and received a basal diet without glycerol to apparent satiation, twice a day, at 8:00 and 17:00 h. The experiment was conducted in a completely randomized design with four treatments $(0,5,10$, and $15 \%$ purified glycerol with $99.75 \%$ purity) (Table 1) and six replicates (tanks). The tanks had a density of 12 fish per replicate.

Fish were randomly divided into 24 circular fiberglass tanks with $70 \mathrm{~L}$ of useful volume, in a water recirculating system with biofilter, sand filter, ultraviolet filter, constant aeration, and water flow sufficient for three total renewals per hour. During the experiment, water temperature was maintained at $29 \pm 0.1^{\circ} \mathrm{C}$ by a temperature controller, Nova PD540, (Precision Digital, Holliston, MA, USA). Dissolved oxygen was measured daily, with a portable digital oximeter, F-1550A, (Beraqua, Indaial, SC, Brazil), with average values of $5.1 \pm 0.9 \mathrm{mg} \mathrm{L}^{-1}$. Ammonia, nitrite, and $\mathrm{pH}$ were measured weekly with a Labcon Test commercial kit (Alcon, Camboriú, SC, Brazil), and the average values obtained were of $0.3 \pm 0.1$, $0.6 \pm 0.1$, and $7.2 \pm 0.2 \mathrm{ppm}$, respectively.

The diets were pelleted, isonitrogenous, and isocaloric, containing $36 \%$ crude protein and $18.84 \mathrm{MJ} \mathrm{kg}^{-1}$ gross energy. Fish were fed to apparent satiation for 60 days, twice a day, at 8:00 and 17:00 h. The tanks were siphoned after each feeding to remove excreta and remaining feed. The proximate composition of the diets was assayed according to the standard methods of Association of Official Analytical Chemists (Association of Official Analytical Chemists, 1995). Briefly, dry matter was measured gravimetrically in oven-dried samples at $105^{\circ} \mathrm{C}$ for 24 hours; ether extract was determined using the Soxhlet system; ash was processed in a muffle at $550^{\circ} \mathrm{C}$ for 4 hours; and crude protein was measured by the Kjeldahl method.

The animals were slaughtered according to the recommendations of the Ethics Committee on Animal Use of Universidade Federal de Lavras, certified by 
protocol No. 008-12. Fish were fasted for 24 hours and anesthetized with benzocaine at a concentration of $100 \mathrm{mg} \mathrm{L}^{-1}$. The juveniles were weighed and their lengths were measured. Approximately $1.0 \mathrm{~mL}$ of blood was collected by cardiac puncture using heparinized syringes and centrifuged at 3,000 $\mathrm{g}$ for $10 \mathrm{~min}$ at room temperature (approximately $22^{\circ} \mathrm{C}$ ). Plasma was separated using a Pasteur micropipette and immediately stored at $-80^{\circ} \mathrm{C}$ for further analysis. The fish were, then, euthanized using an overdose of benzocaine at a concentration of $300 \mathrm{mg} \mathrm{L}^{-1}$. Whole

Table 1. Composition and nutritional value of the experimental diets evaluated as to the growth and energy metabolism of Nile tilapia (Oreochromis niloticus) juveniles.

\begin{tabular}{lcccc}
\hline Ingredients $\left(\mathrm{g} \mathrm{kg}^{-1}\right)$ & \multicolumn{4}{c}{ Glycerol levels $(\%)$} \\
\cline { 2 - 5 } & 14 & 5 & 10 & 15 \\
\hline Corn meal & 0 & 5 & 14 & 14 \\
Glycerol & 20 & 20 & 20 & 20 \\
Soybean meal 45\%(1) & 8 & 7.8 & 7.6 & 7.35 \\
Soybean oil & 1.2 & 1.2 & 1.2 & 1.2 \\
Bicalcium phosphate & 16 & 10.65 & 5.25 & 0 \\
Corn starch & 36.78 & 36.78 & 36.78 & 36.78 \\
Fish meal 65\%(1) & 0.5 & 0.5 & 0.5 & 0.5 \\
Mineral and vitamin premix ${ }^{(2)}$ & 2 & 2 & 2 & 2 \\
Cellulose & 1.5 & 1.5 & 1.5 & 1.5 \\
Gelatin & 0.02 & 0.02 & 0.02 & 0.02 \\
Antioxidant $\left(\mathrm{BHT}^{(1)}\right)$ & 0 & 0.55 & 1.15 & 1.65 \\
Kaolin (inert) & 100 & 100 & 100 & 100 \\
\hline Total & & & & \\
\hline Proximate composition & & & \\
Gross energy $\left(\mathrm{MJ} \mathrm{kg}^{-1}\right)$ & 18.86 & 18.84 & 18.81 & 18.82 \\
Crude protein $\left(\mathrm{g} \mathrm{kg}^{-1}\right)$ & 362.5 & 361.3 & 359.9 & 360.6 \\
Ether extract $\left(\mathrm{g} \mathrm{kg}^{-1}\right)$ & 114.7 & 114.1 & 114.2 & 113.9 \\
Water $\left(\mathrm{g} \mathrm{kg}^{-1}\right)$ & 96.0 & 97.1 & 100.6 & 101.5 \\
Ash $\left(\mathrm{g} \mathrm{kg}^{-1}\right)$ & 79.8 & 78.2 & 80.2 & 81.2 \\
\hline Total indispensable amino acid $\left(\mathrm{g} \mathrm{kg}^{-1}\right)^{(4)}$ & & & & \\
Lysine & 21.3 & 21.3 & 21.3 & 21.3 \\
Methionine & 6.3 & 6.3 & 6.3 & 6.3 \\
Arginine & 19.8 & 19.8 & 19.8 & 19.8 \\
Histidine & 6.9 & 6.9 & 6.9 & 6.9 \\
Isoleucine & 12.9 & 12.9 & 12.9 & 12.9 \\
Leucine & 22.5 & 22.5 & 22.5 & 22.5 \\
Phenylalanine & 13.1 & 13.1 & 13.1 & 13.1 \\
Threonine & 11.7 & 11.7 & 11.7 & 11.7 \\
Valine & 15.5 & 15.5 & 15.5 & 15.5 \\
\hline & & & & \\
\hline
\end{tabular}

(1) Percentage of crude protein. ${ }^{(2)}$ Composition of the vitamin and mineral premix $\left(\mathrm{kg}^{-1}\right): 1,500 \mathrm{IU}$ vitamin $\mathrm{A} ; 15 \mathrm{mg}$ vitamin $\mathrm{B}_{2} ; 1,000 \mathrm{IU}$ vitamin $\mathrm{B}_{3} ; 1,000 \mathrm{IU}$ vitamin $\mathrm{B}_{12} ; 25 \mathrm{mg}$ vitamin $\mathrm{E} ; 120 \mathrm{mg}$ vitamin $\mathrm{PP} ; 2,000 \mathrm{mg}$ choline; $80 \mathrm{mg}$ calcium pantothenate; $2.0 \mathrm{mg}$ folic acid; $170 \mathrm{mg}$ antioxidant butylated hydroxytoluene (BHT); $80 \mathrm{mg} \mathrm{Mn} ; 24 \mathrm{mg} \mathrm{Fe} ; 50 \mathrm{mg} \mathrm{Zn;} 8.0 \mathrm{mg}$ $\mathrm{Cu} ; 3.0 \mathrm{mg} \mathrm{I}$; and $0.1 \mathrm{mg} \mathrm{Se} .{ }^{(3)}$ Values are expressed on as-is basis as the mean of three replicates. ${ }^{(4)}$ Calculated values. liver and approximately $3.0 \mathrm{~g}$ of white dorsal muscle from the same side of the fish were collected and immediately stored without preservative at $-80^{\circ} \mathrm{C}$ for further analysis.

The growth performance parameters analyzed were: final body weight; weight gain, determined as final body weight (g) - initial body weight (g); feed conversion ratio (FCR), calculated as ingested diet $(\mathrm{g}) /$ weight gain $(\mathrm{g}) \times 100$; hepatosomatic index $(\mathrm{HSI})$, determined as liver weight $(\mathrm{g}) /$ body weight $(\mathrm{g}) \times 100$; and survival, calculated as final fish number/initial fish number $\times 100$.

Tissue homogenates were obtained according to Ribeiro et al. (2008) with minor modifications. White muscle samples were diluted in deionized water at a ratio of 1:2 (weight/volume). White muscle was macerated with the aid of a pestle in an ice bath. After soaking, the sample was placed in an ultrasonic bath for $10 \mathrm{~min}$ and centrifuged at 13,400 $\mathrm{g}$ for $5 \mathrm{~min}$ at $4^{\circ} \mathrm{C}$. The supernatant was separated, and the process was repeated twice. The homogenate of the supernatant was used to quantify glucose, total protein, and triglyceride levels. The analyses of metabolites in all tissues were performed using commercial kits.

Liver samples were diluted in $25 \mathrm{mmol} \mathrm{L}^{-1}$ 4-(2-hydroxyethyl)-1-piperazineethanesulfonic acid-potassium hydroxide (HEPES-KOH) buffer at $\mathrm{pH} 7.2$, at a ratio of 1:4 (weight/volume). The liver tissue was also macerated in an ice bath. After soaking, the sample was placed in an ultrasonic bath for $10 \mathrm{~min}$ and centrifuged at $10,000 \mathrm{~g}$ for $30 \mathrm{~min}$ at $4^{\circ} \mathrm{C}$. The supernatant was separated, and the process was repeated two more times. The supernatant of the homogenate was used to determine glucose, total protein, and triglyceride levels, as well as the activities of the malic (enzyme nomenclature EC. 1.1.1.40), glycerol kinase (EC. 2.7.1.30), and glucose-6-phosphate dehydrogenase (G6PD) (EC. 1.1.1.49) enzymes, according to Spina $\mathrm{Jr}$ et al. (1970), Kihara et al. (2009), and Graeve et al. (1994), respectively. All enzyme activity values obtained in the present study are expressed in $\mathrm{U} \mathrm{mg}^{-1}$ protein.

Quantification of glucose was performed with the Glucose HK Liquiform commercial kit (Labtest Diagnóstica SA, Lagoa Santa, MG, Brazil), following Trinder (1969). The measurements were made by a microplate reader with a $340-\mathrm{nm}$ filter, after being incubated at $37^{\circ} \mathrm{C}$ for $5 \mathrm{~min}$. The resulting absorbance 
was compared to a standard glucose kit, which was directly proportional to the glucose concentration in the sample.

Triglyceride quantification was performed with the TG Liquiform commercial kit (Labtest Diagnóstica SA, Lagoa Santa, MG, Brazil), as proposed by Trinder (1969). Measurements were taken with a microplate reader containing a $505-\mathrm{nm}$ filter, after being incubated at $37^{\circ} \mathrm{C}$ for $10 \mathrm{~min}$. The intensity of the red color produced was compared to the standard kit, with the triglycerides in this kit being directly proportional to the concentration of triglycerides in the sample.

The protein concentration was estimated using an equation generated by the reading of solutions containing different concentrations of bovine serum albumin, according to the method described by Bradford (1976).

The specific activity of G6PD was measured at $25^{\circ} \mathrm{C}$ in a buffer consisting of $0.1 \mathrm{~mol} \mathrm{~L}^{-1}$ Tris- $\mathrm{HCl}, \mathrm{pH} 8.0$, $0.2 \mathrm{mmolL}^{-1}$ nicotinamideadeninedinucleotidephosphate (NADP), and $2 \mathrm{mmol} \mathrm{\textrm {L } ^ { - 1 }}$ glycerol-6-phosphate, following the methodology proposed by Graeve et al. (1994). Readings were made in a spectrophotometer at 340-nm absorbance.

The activity of glycerol kinase was determined according to Kihara et al. (2009). The reaction mixture was incubated at $25^{\circ} \mathrm{C}$ in a buffer of $50 \mathrm{~mol} \mathrm{~L}^{-1}$ Tris- $\mathrm{HCl}, \mathrm{pH}$ 8.0, and the concentrations of the formed quinoneimine pigment were monitored by a spectrophotometer at $500 \mathrm{~nm}$.

The determination of the specific activity of the malic enzyme followed the methodology proposed by Spina Jr et al. (1970). The malic enzyme activity was measured at $25^{\circ} \mathrm{C}$ in a buffer containing $100 \mathrm{mmol} \mathrm{L}^{-1}$ triethanolamine- $\mathrm{HCl}, \mathrm{pH} 7.4,100 \mathrm{mmol} \mathrm{L}^{-1}$ solution of L-malic acid, $20 \mathrm{mmol} \mathrm{L}^{-1} \mathrm{~b}$-NADP, and $20 \mathrm{mmol} \mathrm{L}^{-1}$ $\mathrm{MnCl}_{2}$ solution. Measurements were taken in a spectrophotometer at $340 \mathrm{~nm}$.

Analysis of variance (Anova) assumptions were validated by Bartlett's test for homogeneity of variance and the Shapiro-Wilk test for normal distribution of the residuals. Data were subjected to polynomial regression and Anova. Means were compared by the Student-Newman-Keuls (SNK) test, at 5\% probability. Results were presented as means \pm standard deviation. All statistical analyzes were carried out using the computational package Saeg (Universidade Federal de Viçosa, Viçosa, MG, Brazil).

\section{Results and Discussion}

There was no difference between treatments for final body weight, weight gain, hepatosomatic index, feed conversion ratio, and survival (Table 2). These results corroborate those of Neu et al. (2013), who did not find any difference in the growth performance of Nile tilapia fed different levels of dietary glycerol. Li et al. (2010) showed that the use of up to $10 \%$ dietary glycerol for channel catfish (Ictalurus punctatus) did not cause changes in weight gain, feeding efficiency, hepatosomatic index, and survival. However, the inclusion of $20 \%$ glycerol in the channel catfish diet negatively affected their growth performance. Menton et al. (1986) examined glycerol as a source of dietary energy for rainbow trout (Oncorhynchus mykiss) and concluded that the use of glycerol at levels of up to $12 \%$ did not affect fish growth.

In the present study, no differences were observed in the growth performance parameters of the analyzed fish probably because the diets were isonitrogenous and isocaloric, and were composed by high bioavailability ingredients that supplied the nutritional requirements of the species and ensured juvenile growth and healthiness. The diets were also formulated with a protein/energy balance that met the needs of the species used as an experimental model. Furthermore, dietary glycerol has high digestibility as shown by Meurer et al. (2012), who evaluated crude glycerol as an energy source for Nile tilapia. Glycerol presented an apparent digestibility coefficient of 0.89 and a digestible energy content of $13.09 \mathrm{MJ} \mathrm{kg}^{-1}$ as feed basis. Given the great importance of energy metabolism in fish liver, the hepatosomatic index may be altered since the hepatic deposition of lipids, as well as of glycogen, is common.

No significant differences were observed between treatments for the hepatosomatic index, suggesting that lipids deposited in the liver were not sufficient to alter the hepatosomatic index of Nile tilapia juveniles during the experimental period. Menton et al. (1986) also found no significant differences in the hepatosomatic index of rainbow trout fed diets containing 0 and $12 \%$ purified glycerol in the diet.

There was no difference for muscle and plasma glucose (Table 3). These parameters were probably not affected because the fish fasted before euthanasia. Furthermore, glucose is readily available for energy production in muscle activity, being rapidly consumed as an energy source. Menton et al. (1986) found that 
plasma glucose levels were significantly different in trout fed diets with 6 and $12 \%$ glycerol in fasted and fed states. In contrast, trout in both high- and low-energy diets (22 and 9\% fat, respectively), which did not contain free glycerol, showed similar levels of plasma glucose and were not significantly influenced by feeding or fasting state. In the present study, levels of glycerol in the diet did not affect plasma glucose concentrations. Li et al. (2010) found higher levels of glucose in the blood of channel catfish fed diets containing 0 and $5 \%$ glycerol, which decreased in treatments containing 10,15 , and $20 \%$ glycerol used to substitute corn grain. This response cannot be easily explained, given that other carbohydrates, such as starch, and other nutrients also influence circulating glucose levels.

The treatment with $0 \%$ glycerol induced higher hepatic glucose levels than that with $15 \%$ glycerol (Table 3). In general, the level of glycerol in the diet was inversely proportional to the level of glucose in the liver. High hepatic glucose levels in fish from the treatment with $0 \%$ glycerol were probably due to the high level of starch in the diet, since fish from the treatment with $15 \%$, with low starch, showed the lowest mean hepatic glucose level. The ability of this species to maintain homeostasis is one of the main parameters to evaluate the usability of carbohydrates in the diet, as reported by Correa et al. (2007). The use of carbohydrates as an energy source leads to spare protein, which serves a structural function and is used for tissue development (Moura et al., 2007).

There was no difference between treatments in the amount of muscle, plasma, and liver protein (Table 3). These results suggest that dietary glycerol, as well as starch, spared protein catabolism for energy purposes in Nile tilapia juveniles. Glycerol may spare glucogenic amino acids, since it inhibits the glutamate dehydrogenase activity. The regulation of glutamate dehydrogenase activity seems to depend on the source and levels of glycerol in the diet and on the direction of the enzymatic reaction that can convert glutamate into $\alpha$-ketoglutarate and vice-versa (Bernardino et al., 2014). Menton et al. (1986) also found no significant difference in plasma protein concentrations of trout fed

Table 2. Growth performance of Nile tilapia (Oreochromis niloticus) juveniles fed different concentrations of glycerol.

\begin{tabular}{|c|c|c|c|c|}
\hline \multirow[t]{2}{*}{ Parameter } & \multicolumn{4}{|c|}{ Glycerol levels (\%) } \\
\hline & 0 & 5 & 10 & 15 \\
\hline Final body weight ( $\mathrm{g}$ ) & $116.83 \pm 19.03^{\mathrm{ns}}$ & $125 \pm 28.93^{\mathrm{ns}}$ & $111.16 \pm 10.05^{\mathrm{ns}}$ & $108.83 \pm 14.56^{\text {ns }}$ \\
\hline Weight gain $(\mathrm{g})$ & $78.65 \pm 19.03^{\mathrm{ns}}$ & $81.81 \pm 18.93^{\mathrm{ns}}$ & $76.98 \pm 10.05^{\mathrm{ns}}$ & $74.65 \pm 14.56^{\mathrm{ns}}$ \\
\hline Hepatosomatic index (g) & $3.77 \pm 0.75^{\mathrm{ns}}$ & $3.69 \pm 0.71^{\mathrm{ns}}$ & $3.12 \pm 0.42^{\mathrm{ns}}$ & $3.61 \pm 1.16^{\mathrm{ns}}$ \\
\hline Feed conversion ratio & $1.35 \pm 0.42^{\mathrm{ns}}$ & $1.38 \pm 0.51^{\mathrm{ns}}$ & $1.40 \pm 0.39^{\mathrm{ns}}$ & $1.36 \pm 0.44^{\mathrm{ns}}$ \\
\hline Survival (\%) & $89.3 \pm 9.7^{\mathrm{ns}}$ & $92.1 \pm 7.8^{\mathrm{ns}}$ & $91.2 \pm 8.2^{\mathrm{ns}}$ & $90.7 \pm 9.1^{\mathrm{ns}}$ \\
\hline
\end{tabular}

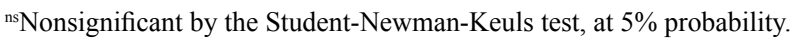

Table 3. Glucose, triglycerides, and protein concentrations in white muscle, plasma, and liver of Nile tilapia (Oreochromis niloticus) juveniles fed different concentrations of glycerol $^{(1)}$.

\begin{tabular}{|c|c|c|c|c|}
\hline \multirow[t]{2}{*}{ Parameter } & \multicolumn{4}{|c|}{ Glycerol levels (\%) } \\
\hline & 0 & 5 & 10 & 15 \\
\hline & \multicolumn{4}{|c|}{ White muscle $\left(\mathrm{mg} \mathrm{g}^{-1}\right)$} \\
\hline Glucose & $1.18 \pm 0.06^{\mathrm{ns}}$ & $1.19 \pm 0.14^{\mathrm{ns}}$ & $1.22 \pm 0.17^{\mathrm{ns}}$ & $1.20 \pm 0.16^{\mathrm{ns}}$ \\
\hline Triglycerides & $14.9 \pm 1.6 \mathrm{c}$ & $15.4 \pm 1.1 \mathrm{c}$ & $17.7 \pm 0.5 b$ & $21.2 \pm 0.9 \mathrm{a}$ \\
\hline \multirow[t]{2}{*}{ Protein } & $245 \pm 13^{\text {ns }}$ & $244 \pm 18^{\text {ns }}$ & $246 \pm 11^{\text {ns }}$ & $245 \pm 15^{\text {ns }}$ \\
\hline & \multicolumn{4}{|c|}{ Plasma $\left(\mathrm{mg} \mathrm{dL}^{-1}\right)$} \\
\hline Glucose & $72 \pm 13^{\mathrm{ns}}$ & $62 \pm 14^{\mathrm{ns}}$ & $63 \pm 12^{\mathrm{ns}}$ & $64 \pm 11^{\mathrm{ns}}$ \\
\hline Triglycerides & $161 \pm 14^{\mathrm{ns}}$ & $150 \pm 21^{\mathrm{ns}}$ & $154 \pm 19^{\text {ns }}$ & $159 \pm 14^{\mathrm{ns}}$ \\
\hline \multirow[t]{2}{*}{ Protein } & $399 \pm 28^{\text {ns }}$ & $393 \pm 25^{\text {ns }}$ & $413 \pm 24^{\text {ns }}$ & $408 \pm 37^{\mathrm{ns}}$ \\
\hline & \multicolumn{4}{|c|}{ Liver $\left(\mathrm{mg} \mathrm{g}^{-1}\right)$} \\
\hline Glucose & $3.05 \pm 0.26 \mathrm{a}$ & $2.80 \pm 0.33 \mathrm{ab}$ & $2.64 \pm 0.35 \mathrm{ab}$ & $2.52 \pm 0.28 b$ \\
\hline Triglycerides & $16.71 \pm 1.33 \mathrm{c}$ & $17.07 \pm 0.85 \mathrm{c}$ & $18.57 \pm 1.57 \mathrm{~b}$ & $21.34 \pm 0.52 \mathrm{a}$ \\
\hline Protein & $193.16 \pm 11.69^{\mathrm{ns}}$ & $191.04 \pm 13.50^{\text {ns }}$ & $190.68 \pm 12.04^{\mathrm{ns}}$ & $192.94 \pm 12.70^{\text {ns }}$ \\
\hline
\end{tabular}

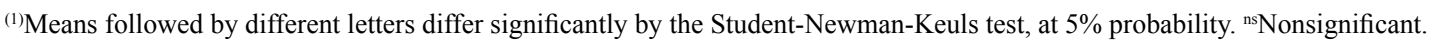


diets with 6 and $12 \%$ glycerol. In contrast, trout fed a high-energy diet had consistently productive protein values, which were significantly higher than of those reared on low-energy diets. This would indicate that glycerol did not spare the utilization and catabolism of dietary proteins as an energy source, as seen with the lipids in high-energy diets.

The levels of glycerol in the diet did not influence the concentration of plasma triglycerides (Table 3 ). There was no change in plasma triglyceride levels probably because the fish were not energetically deficient; therefore, there was no need to mobilize energy, consequently inducing lipolysis in adipocytes. The treatment with $15 \%$ glycerol in the diet presented higher levels of muscle and liver triglycerides. Furthermore, liver and muscle triglyceride concentrations presented significant quadratic regression (Figure 1). The obtained results suggest that Nile tilapia juveniles have the ability to use glycerol as a substrate for tissue lipogenesis, indicating a greater fat deposition in the liver and muscle of fish, a not-desired feature due to the lack of consumer acceptance of fillet fat. However, Li et al. (2010) found significantly lower liver lipid concentrations in channel catfish fed 15 and
$20 \%$ glycerol than in those fed lower glycerol levels. This inconsistency may be related to the different feeding habits of the studied species. Moreover, Nile tilapia, which have a considerable ability to use dietary carbohydrates as an energy source, show a tendency to store dietary glycerol by esterifying it to fatty acids in triglyceride form in tissues.

The treatments with 10 and $15 \%$ of glycerol resulted in higher G6PD enzyme activity, compared to the treatment with $5 \%$ (Table 4). No significant differences were found between treatments for glycerol kinase and malic enzyme activities. In fatty acid formation, metabolic pathways require specific amounts of reduced energy in the form of nicotinamide adenine dinucleotide phosphate-oxidase (NADPH). In fish, the main metabolic source of NADPH is the oxidative phase of pentose phosphate, catalyzed, among other enzymes, by G6PD. The malic enzyme, active in the pyruvate-malate cycle, also contributes for NADPH supply, although in a smaller degree than the oxidative phase of pentose phosphate (Champe et al., 2009), which explains the lower values found in the present study for malic enzyme. Furthermore, pyruvate can also be used for acetyl CoA synthesis, diverting from
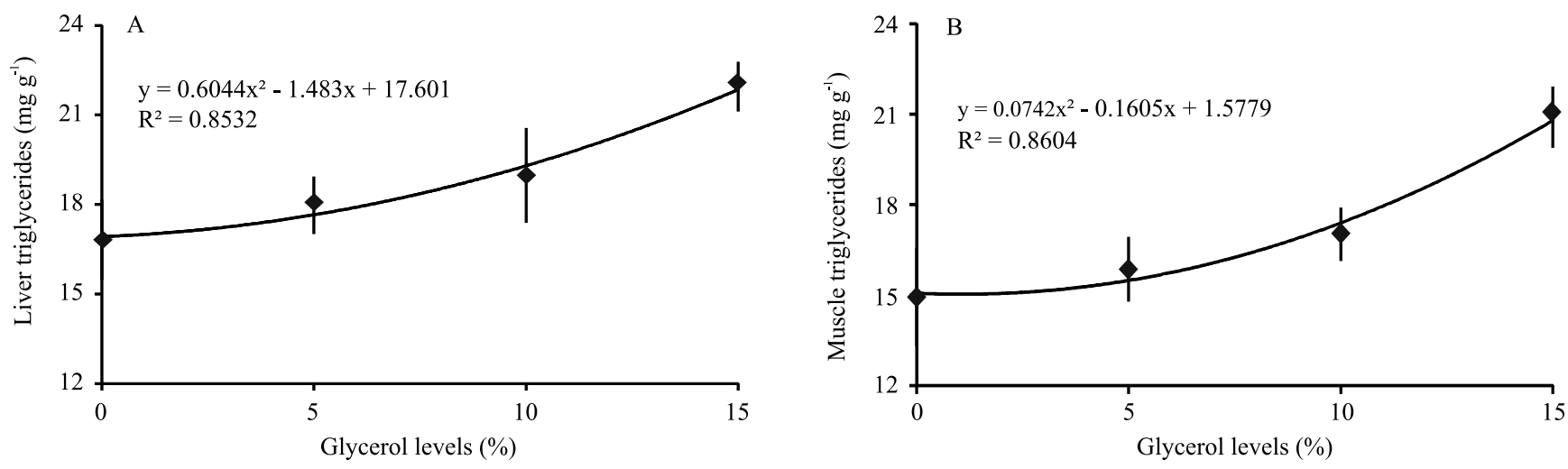

Figure 1. Liver (A) and muscle (B) triglyceride concentrations of Nile tilapia (Oreochromis niloticus) juveniles fed different concentrations of glycerol.

Table 4. Activities of the malic, glycerol kinase, and glucose-6-phosphate dehydrogenase (G6PD) enzymes in liver of Nile tilapia (Oreochromis niloticus) juveniles fed different concentrations of glycerol $^{(1)}$.

\begin{tabular}{|c|c|c|c|c|}
\hline \multirow[t]{2}{*}{ Enzyme } & \multicolumn{4}{|c|}{ Glycerol levels (\%) } \\
\hline & 0 & 5 & 10 & 15 \\
\hline Malic enzyme ( $\mathrm{U} \mathrm{mg}^{-1}$ protein) & $0.053 \pm 0.006^{\mathrm{ns}}$ & $0.052 \pm 0.003^{\mathrm{ns}}$ & $0.055 \pm 0.007^{\mathrm{ns}}$ & $0.056 \pm 0.004^{\mathrm{ns}}$ \\
\hline Glycerol kinase ( $\mathrm{U} \mathrm{mg}^{-1}$ protein) & $0.079 \pm 0.016^{\mathrm{ns}}$ & $0.081 \pm 0.013^{\mathrm{ns}}$ & $0.085 \pm 0.018^{\mathrm{ns}}$ & $0.091 \pm 0.026^{\mathrm{ns}}$ \\
\hline G6PD (U mg-1 protein) & $0.439 \pm 0.016 \mathrm{ab}$ & $0.419 \pm 0.043 b$ & $0.479 \pm 0.018 \mathrm{a}$ & $0.490 \pm 0.052 \mathrm{a}$ \\
\hline
\end{tabular}

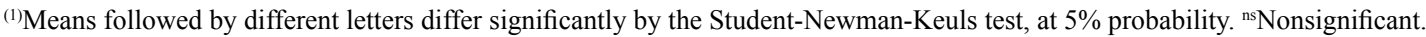


the pyruvate-malate route, without accumulation of malate. Variation in the route activity between different species may be the result of species-dependent differences in the requirement of those metabolites, which can be affected by several factors such as diet composition and physiological state. In fish liver, malic enzyme is little affected by changes on the nature of dietary carbohydrates (Dias et al., 2004). In the present study, no significant differences were observed between treatments in the hepatic activity of the malic enzyme, considering that some authors consider glycerol as a carbohydrate source (Li et al., 2010).

The obtained results suggest that fish fed 10 and $15 \%$ glycerol in their diet used glycerol as the lipogenic substratum in liver and muscle, given the higher activity of the G6PD hepatic enzyme and the higher amount of triglycerides found in these tissues. The glycerol concentrations were enough to supply the energy subsidized for the carbohydrate portion of the diet, diverting the carbohydrate route to the pentose phosphate pathway as evidenced by the increasing G6PD enzyme activity.

Values of glycerol kinase activity in liver fit significant linear regression (Figure 2). Since the phosphorylation of glycerol is necessary for the entry of glycerol into the glycolytic pathway, the level of glycerol kinase in the tissue influences the extent of glycerol utilization (Champe et al., 2009). Even though, in the present study, no significant difference was observed between treatments for hepatic glycerol kinase activity, there was a tendency for increasing values with increasing levels of dietary glycerol. Glycerol kinase is a key enzyme that catalyzes the phosphorylation of glycerol

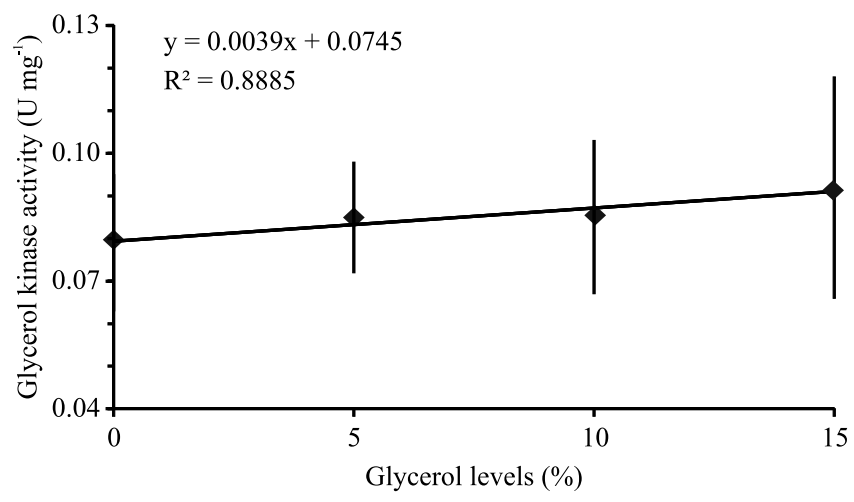

Figure 2. Glycerol kinase activity in liver of Nile tilapia (Oreochromis niloticus) juveniles fed different concentrations of glycerol. to glycerol 3-phosphate. Triglyceride and fatty acid cycling requires the constant generation of glycerol 3-phosphate for triglyceride synthesis, particularly in situations when cycling is increased (Champe et al., 2009), as in fish from the treatment with $15 \%$ dietary glycerol, considering the higher amount of triglycerides in muscle and liver tissues.

The present study shows that glycerol might be a potential energy source in Nile tilapia feeding, corroborating Meurer et al. (2012) and Neu et al. (2013). Menton et al. (1986) suggested that rainbow trout were not efficient in using glycerol as an energy source. The difference between these results could be due to the different dietary habits of the studied fish species, since Nile tilapia is an omnivorous fish and has relative facility to metabolize dietary carbohydrates (Enes et al., 2009). In addition, the yield and use of glycerol as a dietary energy source varies according to animal species and size (Neu et al., 2013). Further studies are needed to trace more accurately the glycerol route in fish metabolism.

\section{Conclusions}

1. Glycerol is a potential alternative energy source to starch in the diet of Nile tilapia (Oreochromis niloticus) juveniles with $37.7 \pm 10.6 \mathrm{~g}$ of initial body weight.

2 . Levels of glycerol inclusion above $10 \%$ in the diet of Nile tilapia juveniles characterize glycerol as a lipogenic nutrient.

\section{Acknowledgment}

To Coordenação de Aperfeiçoamento de Pessoal de Nível Superior (Capes), for financial support.

\section{References}

ASSOCIATION OF OFFICIAL ANALYTICAL CHEMISTS. Official methods of analysis of the AOAC International. $16^{\text {th }}$ ed. Washington: AOAC, 1995.

BERNARDINO, V.M.P.; RODRIGUES, P.B.; NAVES, L. de P.; ZANGERONIMO, M.G.; ALVARENGA, R.R.; ROSA, P.V.; SANTOS, L.M.; TEIXEIRA, L.V. Activity of glutamate dehydrogenase and protein content in the breast of broilers fed diets containing different sources and levels of glycerine. Journal of Animal Physiology and Animal Nutrition, v.98, p.559-568, 2014. DOI: 10.1111/jpn.12113.

BRADFORD, M.M. A rapid and sensitive method for the quantitation of microgram quantities of protein utilizing the 
principle of protein-dye binding. Analytical Biochemistry, v.72, p.248-254, 1976. DOI: 10.1016/0003-2697(76)90527-3.

CHAMPE, P.C.; HARVEY, R.A.; FERRIER, D.R. Bioquímica ilustrada. 4.ed. Porto Alegre: Artmed, 2009. 528p.

CORREA, C.F.; AGUIAR, L.H. de; LUNDSTEDT, L.M.; MORAES, G. Responses of digestive enzymes of tambaqui (Colossoma macropomum) to dietary cornstarch changes and metabolic inferences. Comparative Biochemistry and Physiology A - Molecular and Integrative Physiology, v.147, p.857-862, 2007. DOI: 10.1016/j.cbpa.2006.12.045.

DIAS, J.; RUEDA-JASSO, R.; PANSERAT, S.; CONCEIÇÃO, L.E.C. da; GOMES, E.F.; DINIS, M.T. Effect of dietary carbohydrate-to-lipid ratios on growth, lipid deposition and metabolic hepatic enzymes in juvenile Senegalese sole (Solea senegalensis, Kaup). Aquaculture Research, v.35, p.1122-1130, 2004. DOI: 10.1111/j.1365-2109.2004.01135.x.

ENES, P.; PANSERAT, S.; KAUSHIK, S.; OLIVA-TELES, A. Nutritional regulation of hepatic glucose metabolism in fish. Fish Physiology and Biochemistry, v.35, p.519-539, 2009. DOI: 10.1007/s10695-008-9259-5.

FOOD AND AGRICULTURE ORGANIZATION OF UNITED NATIONS. Fisheries and Aquaculture Department. The state of world fisheries and aquaculture (SOFIA). Rome: FAO, 2014. 223p.

GONÇALVES, L.U.; CEROZI, B. da S.; SILVA, T.S. de C.; ZANON, R.B.; CYRINO, J.E.P. Crude glycerin as dietary energy source for Nile tilapia. Aquaculture, v.437, p.230-234, 2015. DOI: 10.1016/j.aquaculture.2014.12.004.

GRAEVE, K.; VON SCHAEWEN, A.; SCHEIBE, R. Purification, characterization, and cDNA sequence of glucose-6-phosphate dehydrogenase from potato (Solanum tuberosum L.). Plant Journal, v.5, p.353-361, 1994. DOI: 10.1111/j.1365-313X.1994.00353.x.

KIHARA, F.; ITOH, K.; IWASAKA, M.; NIIMI, T.; YAMASHITA, O.; YAGINUMA, T. Glycerol kinase activity and glycerol kinase-3 gene are up-regulated by acclimation to $5^{\circ} \mathrm{C}$ in diapause eggs of the silkworm, Bombyx mori. Insect Biochemistry and Molecular Biology, v.39, p.763-769, 2009. DOI: 10.1016/j. ibmb.2009.09.001.

LI, H.M.; MINCHEW, C.; OBERLE, D.F.; ROBINSON, E.H. Evaluation of glycerol from biodiesel production as a feed ingredient for channel catfish, Ictalurus punctatus. Journal of the World Aquaculture Society, v.41, p.130-136, 2010. DOI: 10.1111/j.1749-7345.2009.00320.x.

LIMA, D.C. de; NETTO, M.V.T.; FELIX, A.P.; BORTOLO, M.; OLIVEIRA, S.G. de; MAIORKA, A. Digestibilidade e energia metabolizável da glicerina em cães. Ciência Rural, v.44, p.1452-1456, 2014. DOI: 10.1590/0103-8478cr20120122.

LIMA, E.M.C.; RODRIGUES, P.B.; ALVARENGA, R.R.; BERNARDINO, V.M.P.; MAKIYAMA, L.; LIMA, R.R.; CANTARELLI, V.S.; ZANGERONIMO, M.G. The energy value of biodiesel glycerine products fed to broilers at different ages. Journal of Animal Physiology and Animal Nutrition, v.97, p.896-903, 2012. DOI: 10.1111/j.1439-0396.2012.01335.x.
MENTON, D.J.; SLINGER, S.J.; HILTON, J.W. Utilization of free glycerol as a source of dietary energy in rainbow trout (Salmo gairdneri). Aquaculture, v.56, p.215-227, 1986. DOI: 10.1016/0044-8486(86)90337-6.

MEURER, F.; FRANZEN, A.; PIOVESAN, P.; ROSSATO, K.A.; SANTOS, L.D. dos. Apparent energy digestibility of glycerol from biodiesel production for Nile tilapia (Oreochromis niloticus, Linnaeus 1758). Aquaculture Research, v.43, p.1734-1737, 2012. DOI: $10.1111 /$ j.1365-2109.2011.02974.x.

MOURA, G. de S.; OLIVEIRA, M.G.A.; LANNA, E.T.A.; MACIEL JÚNIOR, A.; MACIEL, C.M.R.R. Desempenho e atividade de amilase em tilápias-do-nilo submetidas a diferentes temperaturas. Pesquisa Agropecuária Brasileira, v.42, p.1609-1615, 2007. DOI: 10.1590/S0100-204X2007001100013.

NEU, D.H.; FURUYA, W.M.; BOSCOLO, W.R.; POTRICH, F.R.; LUI, T.A.; FEIDEN, A. Glycerol inclusion in the diet of Nile tilapia (Oreochromis niloticus) juveniles. Aquaculture Nutrition, v.19, p.211-217, 2013. DOI: 10.1111/j.1365-2095.2012.00968.x.

OLSEN, R.L.; HASAN, M.R. A limited supply of fishmeal: impact on future increases in global aquaculture production. Trends in Food Science and Technology, v.7, p.120-128, 2012. DOI: 10.1016/j.tifs.2012.06.003.

RETORE, M.; SCAPINELLO, C.; MURAKAMI, A.E.; ARAUJO, I.G.; PONCIANO NETO, B.; FELSSNER, K. dos S.; SATO, J.; OLIVEIRA, A.F.G. Nutritional evaluation of vegetable and mixed crude glycerin in the diet of growing rabbits. Revista Brasileira de Zootecnia, v.41, p.333-340, 2012. DOI: 10.1590/ S1516-35982012000200015.

RIBEIRO, P.A.P.; LOGATO, P.V.R.; PAULA, D.A. de J.; COSTA, A.C.; MURGAS, L.D.S.; FREITAS, R.T.F. de. Efeito do uso de óleo na dieta sobre a lipogênese e o perfil lipídico de tilápias-do-nilo. Revista Brasileira de Zootecnia, v.37, p.1331-1337, 2008. DOI: 10.1590/S1516-35982008000800001.

SHIELDS, M.C.; VAN HEUGTEN, E.; ODLE, J.; STARK, C.S. Impact of crude glycerol on feed milling characteristics of swine diets. Animal Feed Science and Technology, v.175, p.193-197, 2012. DOI: 10.1016/j.anifeedsci.2012.05.008.

SPINA JR, J.; BRIGHT, H.J.; ROSENBLOOM, J. Purification and properties of L-malic enzyme from Escherichia coli. Biochemistry, v.9, p.3794-3801, 1970. DOI: 10.1021/bi00821a019.

TRINDER, P. Determination of glucose in blood using glucose oxidase with an alternative oxygen acceptor. Annals of Clinical Biochemistry, v.6, p.24-27, 1969. DOI: $10.1177 / 000456326900600108$.

UNITED STATES FOOD AND DRUG ADMINISTRATION. Code of federal regulations. Title 21: food and drugs. Subchapter B: food for human consumption. Part 182: Substances generally recognized as safe. Silver Spring: FDA, 2013. Available at: $<$ http:// www.accessdata.fda.gov/scripts/cdrh/cfdocs/cfcfr/CFRSearch. cfm?CFRPart=182>. Accessed on: 9 May 2013.

Received on May 21, 2014 and accepted on April 1 ${ }^{\circ}, 2015$

Pesq. agropec. bras., Brasília, v.50, n.5, p.347-354, maio 2015

DOI: 10.1590/S0100-204X2015000500001 